\title{
Pohybové hry jako metoda nácviku gymnastických dovedností ve školní tělesné výchově
}

\section{Movement games as a learning method of gymnastics skills at school physical education}

\author{
Jitka Vorálková, Tomáš Perič \\ Fakulta tělesné výchovy a sportu, Univerzita Karlova v Praze
}

\begin{abstract}
Abstrakt
Pozitivní pohybové zkušenosti a silné emotivní zážitky zvyšují účinnost vyučovacího procesu. Efektivity vyučovací jednotky může učitel tělesné výchovy dosáhnout různými metodami, avšak mezi nejúčinnějši radíme využití bohaté palety pohybových her. Hru lze považovat v oblasti školní tělesné výchovy jako vhodný prostředek pro rozvoj a zvyšování úrovně nejen kondičních a koordinačních schopností, ale také jako prírozenou metodu pro nácvik základních gymnastických dovedností. Zvýšené atraktivity her můžeme dosáhnout vhodně zvoleným gymnastickým náradím a jeho kombinacemi či seskupením. Moderní technologie umožňuje výrobu takového nářadí, jehož design motivuje děti ke cvičení a snadná manipulace snižuje psychické zábrany a výrazně zvyšuje bezpečnost všech cvičenců.
\end{abstract}

\begin{abstract}
Positive motion experience and strong emotional experiences increase efficiency of the teaching process. Physical education teachers may achieve effectiveness of a teaching unit using various methods. A wide range of movement games belong among the most efficient ones. Physical education games may be considered a suitable tool to develop and enhance both fitness and coordination abilities and a natural method to learn basic gymnastics skills. Higher attractiveness of games can be achieved by suitably chosen gymnastics tools, its combination or groupings. Modern technology allows production of such tools whose design encourages children to exercise and easy handling reduces mental inhibitions and increases safety of all gymnasts.
\end{abstract}

\section{Klíčová slova}

Hra, herní princip, gymnastika, školní tělesná výchova

\section{Key words}

Game, game principle, gymnastics, school physical education

Př́spěvek je součástí projektu PRVOUK P 15, Univerzity Karlovyv Praze, FTVS.

\section{Úvod}

Z historie lidského vývoje vyplývá, že o významu gymnastických cvičení není potřeba pochybovat. Obsah těchto cvičení se vlivem rozvoje poznatků člověka přizpůsoboval potřebám společnosti. Kössl, Štumbauer a Waic (2002) uvádějí, že v jednotlivých obdobích a vývojových etapách byl význam gymnastických cvičení různý - zábava králů, vysoká péče o hygienu těla, léčebná a výchovná funkce, zdokonalování fyzické kondice vojáků, udržení a obnova zdraví atd. Stěžejní cíle však zůstaly zachovány dodnes. Hlavním významem gymnastických cvičení zůstávají jejich zdravotní účinky na lidský organismus. Podle Skopové \& Zítka (2005) je preferováno především upevnění zdravotně orientované tělesné zdatnosti, zejména pak utváření návyku individuálně optimálního držení těla. Současné př́stupy výuky gymnastickým dovednostem ve školní tělesné výchově je nutné orientovat 
tedy takovým směrem, který plně podporuje pohybový rozvoj dítěte a zároveň jeho fyzickou zdatnost. Smyslem gymnastických aktivit by mělo být spíše naučit děti ovládat své tělo, než vykonávat dovednost dokonalým způsobem. Tohoto cíle lze dosáhnout výběrem takové aktivity, která podle Wernera (2004) umožňuje začlenění všech studentů do vyučovacího procesu. Proto je důležité organizovat a připravovat takové gymnastické programy, které budou dětem vytvářet nejen produktivní, ale především prostředí s vysokým prožitkem. V procesu pohybového učení lze docílit zájmu dětí o gymnastické aktivity prostřednictvím různých pohybových her. Zvláštní pozornost, zaměřenou především na zábavné a herní pojetí gymnastických aktivit, preferuje mezinárodní gymnastická federace (FIG) ve svém celosvětově uznávaném vzdělávacím systému. Tento propracovaný vzdělávací systém je založen na naplnění filosofie tzv. „,4 F“. Obsah jednotlivých „ „F“ vyjadřuje: 1 ) Fun - bavte se a užívejte si legrace, 2) Fitness - získejte přiměřenou tělesnou zdatnost, 3) Fundamentals - osvojte si dobré pohybové základy, 4) Friendship - užívejte si přátelské vztahy a vytvářejte nová přátelství (Ahlquist, Russell, Fink et al., 2010). Pokud budou žáci v prováděných činnostech gymnastického charakteru úspěšní po většinu času jejich trvání, lze jednoznačně souhlasit s výzkumy Ashy, Lee \& Landin (1988) a Silverman (1993), že úspěšnost v hodinách pozitivně ovlivňuje výsledek studentových činností. V takových případech se dá očekávat vysoká prožitkovost a tím i zvýšený zájem o gymnastické aktivity.

Výrazně specifickým znakem sportovní gymnastiky jsou vysoké nároky na pohyb na pažích a překonávání hmotnosti vlastního těla cvičence přes množství různých poloh (např. postoje, kleky, sedy, lehy podpory, visy...). Rozmanitost a stř́dání nekonečného množství pozic jak na zemi, tak na jednotlivém nářadí, vytváŕí široké spektrum pohybových zkušeností, které pozitivně přispívají ke stimulaci koordinačních předpokladů. Většinu výše jmenovaných pohybových struktur můžeme také uplatnit ve hrách a soutěžích, pomocí kterých můžeme ovlivnit pohybové schopnosti dětí. Tím zároveň vytváříme důležité předpoklady i pro nácvik gymnastických dovedností. Dvořáková (2009) zároveň upozorn̆uje, že v konkrétní hře je nutné zvládat základní pohybové dovednosti a užívat je s ohledem na pravidla hry.

\section{Herní princip}

Významem her v obsahu školní tělesné výchovy či sportovní př́ipravy se u nás i ve světě věnuje mnoho autorů (Mazurovová \& Vlasáková, 1992; Mazal, 2000; Perič, 2012; Vorálková, Novotná \& Šimůnková, 2013; Butler, 2005; Huizinga, 1955 aj.). Herní princip ve vyučovacím procesu je spojen se spontánností, emocionálností a pozitivním prožitkem dětí a možností jejich rozhodování o obsahu a intenzitě činnosti. Z obsahového hlediska je herní princip charakteristický zařazováním vysokého podílu her do vyučovacího či tréninkového procesu. Perič (2012) uvádí, že pro herní princip jsou charakteristické dva základní aspekty: 1) implicitní učení - které lze chápat podle Cleeremanse (2002) jako osvojování nové informace, aniž bychom to měli v úmyslu, kde výslednou znalost je těžké vyjádřit, 2) výrazný prožitek (ve smyslu FLOW), které Csikszentmihalyi (1996) popisuje jako provozování činnosti se zaujetím, motivací, pozitivním naladěním a bez uvědomění si času, který činnosti věnujeme. Podle Americké aliance pro zdraví, tělesnou výchovu, rekreaci a tanec $\left(\right.$ AAHPERD $\left.^{1}\right)$ jsou učitelé a trenéři odpovědní za učení her, dovedností nebo sportovních činností a za naučení, jak hru hrát a tím přispět k rozvoji životních dovedností (Feingold \& Fiorentino, 2005).

\subsection{Hraní si a pohybová hra}

Pod pojmem hraní chápe Mazal (2000) záměrnou pohybovou aktivitu jednoho i více lidí, v prostoru a čase, bez složitých pravidel. Hraní nemá přesná pravidla, jsou vymezena obsahem pohybové aktivity. Jsou charakterizována vysokou motivací k činnosti, napětím a uplatněním známých dovedností. V průběhu hraní se dá soutěžit i spolupracovat. Zajímavý pohled na hraní přináší Berne (1992),

1 AAHPERD - American Alliance for Health, Physical Education, Recreation and Dance - je americká organizace, která propaguje a podporuje výzkum, vzdělávání a osvědčené postupy v profesích, které podporují kreativní, zdravý a aktivní životní styl. 
který ho popisuje jako součást života lidí a jejich každodenního chování. Perič (2004) uvádí, že malé děti (5-9 let) si chtějí hrát a jejich hry jsou většinou nesoutěžního charakteru, nepotřebují srovnání vítěz - poražený. Podstatou jejich her je vlastní hraní si - tvůrčím způsobem rozvíjet určitý motiv. U starších dětí (9+) přechází potřeba hrát si do potřeby hry. Ta má většinou jasně vymezená pravidla, je zde určitý pevný průběh a hra končí vítězstvím či prohrou. Mazal (2000) definuje pohybovou hru jako záměrnou, uvědoměle organizovanou pohybovou aktivitu dvou a více lidí, v prostoru a čase, s předem dobrovolně dohodnutými a bezpodmínečně dodržovanými pravidly. Je charakterizována napětím, radostí, veselím, vysokou motivací k činnosti, uplatněním známých dovedností, pohodou a často soutěživostí.

V současné sportovní praxi se můžeme mnohdy setkat s užíváním termínu hra i v jiném kontextu, napřr. soutěž či závod. Klasickým př́kladem tohoto trendu je používání termínu štafetové hry, ve smyslu štafetové závody. Ačkoliv se v tomto př́ípadě nejedná o hru ve smyslu střetnutí dvou soupeřů, jejichž cílem je prostřednictvím vybojování si prostoru a času skórovat, přesto můžeme říci, že v určitém přeneseném významu tyto soutěže naplňují výše uvedený herní princip (ve smyslu implicitního učení a flow). Z tohoto důvodu bude také v následujícím textu užíván termín hra i pro činnosti, které by mohly být vnímány spíše jako závody.

\subsection{Klasifikace a rozdělení her}

Tématem hry se v minulosti zabývalo a v současnosti stále ještě zabývá celá řada autorů. Existuje mnoho př́stupů $\mathrm{k}$ dělení her. Rozdělení her není jednotné a jejich rožrazení do jednotlivých kategorií se ukazuje jako problematické. Rozdílné pojetí tř́ídění her mnoha autorů vychází z odlišných modelů. Zapletal (1985-1988) ve své encyklopedii her dělí hry na Hry v př́rodě, Hry v klubovně, Hry na hřišti a v tělocvičně a Hry ve městě. Dostál \& Opravilová (1985) klasifikují hry podle schopností, které hry předpokládají na smyslové, pohybové a speciální nebo z hlediska předmětů, které se ve hře vyskytují, rozlišují hry funkční, konstruktivní a fiktivní. Další možnost je podle autorů rozdělit hry podle místa na interiérové a exteriérové, z hlediska počtu hráčů na individuální, párové a skupinové. Bakalář (1989, 1995) své pojetí her zužuje do Psychoher a dělí je na Hry seznamovací, rozehřívací, Hry didaktické, Hry pro rozvoj tvořivosti, Hry sebepoznávací a Hry s kombinovaným zaměřením. Do členění her přispěl také Neuman (1998, 1999), který je třídí na Seznamovací hry, Zahřívací a kontaktní hry, Hrátky a zábavné soutěžení, Hry na rozvoj důvěry, Iniciativní a týmové hry, Hry na rozvoj komunikace a spolupráce, Hry a cvičení v přírodě, Ekohry, Závěrečné hry a ceremoniály, Hry na reflexi a závěrečné hodnocení. Caillois (1998) přichází s typologickou analýzou hry, která hru rozděluje do čtyř základních skupin - agón, alea, mimikry a ilinx. Zcela odlišný přístup uvádí Perič (2012), který kategorizuje hry užívané ve sportovní přípravě dětí do čtyř tematických skupin:

1) hry dovednostní, jejichž cílem je jak nácvik nových dovedností, tak aplikace již naučených dovedností ve větších motorických celcích (sériové či paralelní dovednosti) či v proměnlivých podmínkách

2) hry pro rozvoj schopností, které dělí na zábavné a stimulační

3) hry, které navozují rozhodovací procesy v soutěžních situacích a dělí je na hry s řešením problémů a hry na řešení soutěžně situačních rolí.

4) hry zaměřené na nácvik spolupráce, tedy skupiny her komunikačních a kooperačních.

\section{Využití her s gymnastickým obsahem ve vyučovací jednotce školní tělesné výchovy ${ }^{2}$}

Pohybové hry je možno využít v kterékoli části vyučovací jednotky. Zařazeny mohou být bud' v úvodu jako prostředek k zahřátí organismu nebo naopak v závěru k jeho částečnému uklidnění. Vhodně zvolené hry dovednostní mohou být i v hlavní části vyučovací jednotky a mohou tak přispívat k roz-

2 Při výběru her jsme vycházeli z odborné literatury zabývající se pohybovými hrami, která je uvedena v kapitole Literatura. 
voji všestrannosti, ovlivňovat vybrané složky tělesné zdatnosti a přspívat k celkovému kondičnímu rozvoji cvičence.

Pohybové hry do vyučovací jednotky nikdy nevybíráme pouze jen jako zábavu. Každá hra by měla mít svůj cíl, kterého si přejeme dosáhnout. Účelem her tedy není jen vyplnění času ve vyučovací jednotce, ale v oblasti vzdělávání představuje hra zajímavou výukovou metodu. Př́nosem realizace pohybových her je i rozvoj cenných morálně - volních vlastností (Mazurovová \& Vlasáková, 1992), zejména při překonávání překážek, vytvořených různým seskupením gymnastického nářadí nebo při odbourávání psychických bariér (zejména strachu) ve vyskytujících se neobvyklých polohách těla. Děti by se měly vždy těšit na to, co nového se naučí a jakou zábavu prožijí. Pohybové hry jsou i jedním z nejefektivnějších prostředků, které umožňují integraci fyzické, psychické a sociální složky osobnosti.

\subsection{Gymnastické hry}

Gymnastické hry dělí Zítko a kol. (2000) na hry bez náčiní a nářadí a hry s využitím nářadí (hry na kladině, hry na žebříku, hry na kruzích, hry na šplhacím nářadí, hry v akrobacii) a náčiní. Tyto dvě skupiny her dále člení na honičky (honičky se změnou lokomoce, honičky se stálým chytačem, honičky s „hradou“ - využívají možnosti honěného zachránit se před chytačem tím, že splní stanovený pohybový úkol, způsoby záchrany jsou předem dohodnuté a jsou určovány s didaktickým záměrem), závodivé hry a napodobivé hry. Díky možnosti použití různorodého náčiní a nářadí, mohou mít gymnastické hry také dobrodružný charakter. A tak se cvičenci nenásilnou formou učí překonávat strach a obavy z nových dovedností.

\subsection{Hry vhodné do úvodní části vyučovací jednotky:}

Do této části většinou zařazujeme hry s vysokou dynamikou, při kterých jsou neustále zapojeni všichni cvičenci. Při větším počtu cvičenců můžeme určit více chytačů (těch, co mají babu). Důležité je vymezit prostor, kde se honička hraje a využívat různých variant, aby se udržela intenzita cvičení a motivace dětí. Pravidla her by měla být jednoduchá, snadno zapamatovatelná, aby mohla rychle a dobře probíhat již od samého začátku. Podle Neumana (2001) je pro tyto hry charakteristické navození pohody, radostné nálady a chuti do další činnosti. Vždy bychom měli vybírat takové hry, které budou mít návaznost na hlavní část vyučovací jednotky.

\section{HONIČKY}

Honičky se změnou lokomoce:

„Krabí honička“ - honič (chobotnice) pronásleduje ostatní cvičence, koho se dotkne, stane se jeho zajatcem (krabem). Ten pak pomáhá honiči v pronásledování ostatních v poloze - vzporu vzadu ležmo, dokud nezůstane $\mathrm{v}$ poli pouze jeden hráč. Po té se $\mathrm{z}$ honiče také stane krab a všichni pronásledují posledního hráče. Ten se pak stává honičem.

„Vrabčí honička“ - určený hráč pronásleduje ostatní hráče a v ruce drží míč. Úkolem honícího hráče je dotknout se míčem jiného hráče. Pokud se tak stane, je tomuto hráči předán míč a stává se honičem. Míč se během hry nesmí házet a pronásledovaní se pohybují pouze ve vymezeném prostoru poskoky obounož.

Honičky se záchranou - dle Zítka a kol. (2000) s „hradou“:

„Želví honička“ - honěný se může před honičem zachránit podporem na předloktí klečmo a skloněním hlavy, čímž napodobuje želvu. $V$ této poloze může setrvat pouze $5 \mathrm{~s}$ a potom musí zase běžet. Pokud se jej honící hráč dotkne dříve, než stačí provést zadanou polohu, jejich role se mění a chycený cvičenec se stává honičem. 
Honičky se stálým honičem:

„Mrazík“ - jeden nebo více určených hráčů pronásleduje ostatní. Hráč, kterého se honič dotkne „zmrzne“ a čeká ve stoji rozkročném na vysvobození podlezením spoluhráče. Pro obměnu může chycený hráč zaujímat různé polohy - např. vzpor ležmo, vzpor vzadu ležmo, vzpor stojmo apod.

„Honička dvojic“" - různé varianty držení dvojic a jejich změny mohou navrhovat samotní cvičenci, zároveň i různé způsoby lokomoce.

\section{HRY VE SKUPINÁCH}

„Vyměň hnízdo" - cvičenci jsou rozděleni do čtyř družstev a každé družstvo představuje nějaký druh ptáčka (napřr. vrány, sýkorky, kosi, holuby). Každé družstvo má v rohu tělocvičny svoji žíněnku „hnízdo“. Na zvolání učitele, např. „vrány - holuby“, si obě družstva předem určenou dráhou vymění „hnízda“. Vítězí družstvo, které se rychleji přemístí.

„Koš plný ovoce“ - tato hra má podobný průběh jako hra „Vyměň hnízdo“. Když učitel zvolá „koš plný ovoce“", musí si co nejrychleji vyměnit místo každé družstvo.

„Dračí hlava honí ocas“ - lovení „ocáskư“ (švihadel). Cvičenci vytvoří čtyři až pět družstev. První z družstva představuje „dračí hlavu“, poslední cvičenec má za pasem zastrčené švihadlo tak, aby bylo vidět, nebot’ je to „ocas“ draka. Každé družstvo se musí stále držet za ramena nebo za boky. První cvičenec se snaží získat co nejvíce „ocáskư“ soupeřících družstev.

„Rybičky, rybáři jedou“ - jeden cvičenec stojí na jedné straně tělocvičny či jiného vymezeného prostoru, ostatní cvičenci se nacházejí na straně druhé (protilehlé). Na znamení vybíhají cvičenci proti sobě, koho se rybář dotkne, stává se také rybářem. Rybáři smějí běžet pouze vpřed, nesmějí se vracet. Poslední nechycený cvičenec je vítěz a stává se rybářem v nové hře. Stejný průběh má i hra „Na ovečky a vlka“".

„Gorily a paviáni““ - cvičenci jsou rozděleni na dvě skupiny. Jedna skupina má šátky nebo švihadla (ocásky) zastrčená za pasem, představují paviány. Druhá skupina cvičenců nemá ocásky, jsou gorily. Gorily se snaží paviánům šátky nebo švihadla vytáhnout. Paviáni, kteří ztratili ocas, se stávají gorilami a hra pokračuje, dokud se všichni nestanou gorilami (bez ocásků).

„Př̀ekážkové dráhy“ - rozdělení cvičenců do jednoho, dvou či třech družstev (podle počtu cvičenců), jeden cvičenec vede ostatní ze svého družstva po tělocvičně. Volí různou trasu přes libovolné překážky (vše v rámci bezpečnosti).

„Na vrabce a kocoura“ - po hrací ploše jsou rozmístěny lavičky, které představují „hnízda“. Cvičenci (,vrabci“) stojí na lavičkách a dívají se do středu hrací plochy, kde sedí jeden cvičenec („,kocour“) a předstírá, že spí. „Vrabci“ seskočí z lavičky a pohybují se určeným způsobem po hrací ploše (poskoky obounož, jednonož apod.). Jakmile „kocour“ uslyší „,vrabce“, jeho úkolem je jich co nejvíce pochytat. „Vrabci se mohou zachránit před „kocourem“ rychlým úprkem do svých „hnízd“ a nesmí z nich spadnout.

\subsection{Hry vhodné pro hlavní část vyučovací jednotky:}

Do této části vyučovací jednotky zařazujeme hry na rozvoj pohybových schopností a dovedností (síly, rychlosti, vytrvalosti, koordinace, specifické dovednosti). Můžeme využít různé druhy náčiní nebo nářadí. Jejich prostřednictvím se cvičenci seznamují s vlastnostmi gymnastického nářadí.

\section{ZÁVODIVÉ HRY}

Štafetové hry - podle Mazala (2000) je můžeme nazvat soutěživé závody v družstvech.

Překážkové dráhy - předem určená dráha s využitím velké škály pomůcek či nářadí. Seskupení jednotlivého nářadí můžeme různě obměňovat. Lze měřit čas jednotlivce nebo soutěžit ve dvojicích či v družstvech. 
„Míčová válka“ - dvě stejně početná družstva jsou rozmístěna $v$ řadě proti sobě podél kratší stěny tělocvičny. Každý z cvičenců má plný míč (medicinbal). Na znamení všichni začnou kutálet míč do soupeřova pole přes půlící čáru. Každý se ihned snaží kutálením vracet soupeři každý další míč z vlastní poloviny hřiště. Na zvukový signál všichni přestanou a nikdo už se nesmí dotknout žádného míče. Vyhrává družstvo, které má po ukončení hry na své polovině menší počet míčů.

\section{NÁMĚTOVÉ HRY}

„Sochy“ - cvičenci jsou rozděleni do družstev po osmi až deseti. Učitel určí bud’ návrh sochy, co by měla zobrazovat nebo stanoví kolik rukou a kolik nohou smí mít společná socha na zemi. Každé družstvo se snaží co nejrychleji zobrazit tematické zadání sochy nebo zaujmout takovou polohu, aby se země dotýkali jen určené části těla.

„Živé obrazy“ - členové každé skupiny vytváŕí vlastními těly náměty různých obrazů - např̀. zvířata, rostliny, typické stavby, známé sousoší apod.

„Improvizace“ - s využitím hudebního doprovodu.

„Zrcadlo“ - jeden cvičenec vyjadřuje pohybovým projevem např. různé emoce, činnosti typické pro jednotlivá povolání apod. Ostatní se ho snaží napodobovat tak, aby to vypadalo, že jsou jeho zrcadlem. Cvičenec, který předvádí, nesmí dělat př́liš rychlé pohyby.

\section{HRY S VYUŽITÍM AKROBATICKÉHO PÁSU NEBO KOBERCE - jednotlivci,} ve dvojicích, ve trojicích (zvýšení prožitkovosti, spolupráce a vzájemné důvěry).

Hry pro nácvik či opakování kotoulu vpřed:

„Trakař‘ - dvojice cvičenců, jeden je ve vzporu ležmo, druhý jej uchopí za nárty, cvičenec ve vzporu ručkuje vpřed a druhý cvičenec jej po třech krocích zdvíháním nártů vede do kotoulu vpřed. Vítězí dvojice, která se nejrychleji dostane tímto způsobem k určené metě.

„Siamská dvojčata“ - kotouly ve dvojicích. Vítězem se stává dvojice, která se dříve dostane k určené metě, nebo která se dokutálí bez rozpojení dále.

Hry pro nácvik zpevňování těla:

„Dopravní pás“ - družstvo cvičenců zaujímá na akrobatickém pásu vedle sebe polohu - leh, vzpažit. Jeden ze cvičenců provede leh na břiše, vzpažit a položí se kolmo na těla svých spolucvičenců. Válením „sudů“ skupiny cvičenců se horní cvičenec posouvá jako po dopravním pásu na začátek skupiny ležících cvičenců, poté se přidává $\mathrm{k}$ nim a také současně provádí válení „sudů“. Cvičenec, který je na začátku „dopravního pásu“ stř́dá cvičence, který se před ním pohyboval po „dopravním pásu“ a toto stř́ídání se stále opakuje, dokud cvičenci nedorazí k vyznačené metě. Předpokladem fungování celé skupiny cvičenců je zpevněné tělo všech.

„Prkénko“, „Mistička“, „Hř́ibek“, „Velbloud“, „Klubíčko“; „Vojáček“; „Hodiny“ - rychlé změny různých poloh těla a jejich provedení. Vítězem se stává cvičenec, který má nejvíce bodů za rychlé zaujmutí určené polohy.

„Tlačení válce“ - soutěž dvojic či trojic - jeden cvičenec je na podložce ve zpevněné poloze - leh, vzpažit. Druhý (případně i třetí) cvičenec tlačí do ležícího tak, že ho posunuje na určené místo, vyznačené metou, jako při válení sudů. Všichni členové družstva se vystř́dají na pozici „tlačeného válce“. Vítězí družstvo, které „dotlačí válec“ co nejrychleji do cíle.

„Létající ryba“ - skupina cvičenců si lehne na zem do řady tak, že mají hlavy vedle sebe a nohy na jednu či druhou stranu. Všichni předpaží a na takto připravené a pevné paže si zády lehne jeden cvičenec. Skupina ho posouvá z jednoho konce na druhý. Tohoto cvičence doprovází vždy ještě jeden, aby zajistil dopomoc při zakončení pohybu, kdy posunovaný přestává mít jištěnou hlavu. 
Hra pro nácvik výdrže ve stoji na rukou:

„Stojkový král““ - kdo vydrží déle ve stoji na rukou.

Hra pro nácvik obratnosti:

„Kuba řekl...“ - rychlé provedení různých úkolů - kdo splní zadaný pohybový úkol nejrychleji, počítá si bod. Kdo má nejvíce bodů stává se vítězem.

2.4 Hry vhodné pro závěrečnou část vyučovací jednotky:

V této části vyučovací jednotky zařazujeme hry, jejichž cílem je uklidnit cvičence po předchozí pohybové činnosti.

„Námořník“ - přechod lavičky (kladiny) s výměnou místa s cvičencem na druhé straně „Chůze s lehkým předmětem na hlavě““

„Oblékání“ - cvičenci se postaví na kladinu, v ruce mají tepláky, mikinu a ponožky. Jejich úkolem je co nejrychleji se obléci a nespadnout při tom z kladiny.

„Balancování“s s gymnastickou tyčí - v dlani, na nártu, při chůzi na kladině.

\section{Gymnastické nářadí}

Z hlediska využívání jednotlivých nářadí je rozhodující účel jejich použití. Zatímco, ve sportovních formách cvičení na nářadí jsou jednotlivá nářadí označována jako disciplíny gymnastického víceboje a cvičební obsah je dán pravidly sportovní gymnastiky s cílem podávat individuálně maximální sportovní výkon, v oblasti školní tělesné výchovy (potažmo sportu pro všechny) je účelem nářadí:

- využití konstrukce nářadí pro zvýšení fyziologického účinku cvičení

- osvojování si nových koordinačně náročných dovedností

- tvorba intervenčních programů

- vytváření modifikovaných „překážek“, které je nutné prostřednictvím lokomočních pohybů překonávat apod. (Chrudimský a kol., 2012).

$\mathrm{Na}$ atraktivitě her se může podílet využívání rozličného nářadí. Většina standardních gymnastických nářadí svými vlastnostmi neodpovídá možnostem dětského organismu. Proto řada výrobců gymnastického nářadí vyrábí speciální nářadí určená pro děti předškolního případně mladšího školního věku. Takovéto nářadí nalezne své uplatnění i u starších cvičenců. Jejich účel je totožný jako u standardního nářadí, ale jejich konstrukce, tvar, použité materiály i velikost je modifikována. Jejich účelem využití v didaktice gymnastiky je stimulace a podpora rozvoje funkčních předpokladů cvičenců. Svojí konstrukcí, použitými materiály a způsobem zpracování zvyšují bezpečnost nácviku gymnastických dovedností a usnadňují jejich realizaci. Jejich design motivuje cvičence ke cvičení a snižuje psychickou náročnost cvičení. Využívání takového nářadí zvyšuje nejen efektivitu cvičení, jeho bezpečnost, ale i motivaci cvičenců na aspiraci jejich výkonů.

\subsection{Hry s využitím gymnastického nářadí}

„Abeceda“ - nejvýšse pět cvičenců se pověsí na hrazdu vedle sebe. Jejich úkolem je následně seřadit se podle jmen $\mathrm{v}$ pořadí podle abecedy.

„Ostrovy“ - cvičenci jsou rozděleni do 2 - 4 družstev. Každé družstvo má k dispozici dvě měkké žíněnky, s jejichž pomocí se musí co nejrychleji přepravit přes tělocvičnu, aniž by se někdo dotkl podlahy.

„Plovoucí lavička“" - lavička je položená horní deskou na 8 gymnastických tyčích. Jeden ze cvičenců zaujme stabilní polohu na úzké ploše lavičky. Ostatní cvičenci posunují lavičku se cvičencem 
po tyčích. Zároveň přendávají tyče $\mathrm{z}$ jednoho konce na druhý pod lavičku tak, aby byla stále v pohybu a mohla se po tyčích posouvat vpřed.

„Skákavé okénko“ - cvičenci se rozdělí do čtveřic. Každá čtveřice stojí v zástupu za startovní čárou. Proti jednotlivému zástupu se nachází 1 díl švédské bedny. Na signál vybíhá naráz celá čtveřice ke svému dílu švédské bedny. Dva cvičenci skočí dovnitř tohoto dílu do dřepu. Zbývající dva uchopí díl bedny na kratší straně, přenesou jej přes hlavy cvičenců, položí před ně zpět na zem a skočí do dílu bedny oni. Cvičenci, kteří byli uvnitř dílu, mezitím provedou stoj a prebírají funkci svých kolegů, tzn., že opět přenesou díl bedny přes hlavy cvičenců. Toto cvičení se opakuje, dokud čtveřice nedosáhne vyznačené mety.

Hry na kladině:

„Na dirigenta“ - změny poloh - jeden cvičenec - „dirigent“ předvádí různé polohy, ostatní je opakují. Kdo první spadne, stává se „dirigentem“.

„Přihrávaná“ - sám sobě cvičenec nadhazuje míč a provádí př̀i tom různé taneční kroky - soutěž dvojic, komu nespadne míč a udrží se na kladině, získává bod; cvičenec na kladině si přihrává se cvičencem na zemi a provádí různé způsoby lokomoce.

\section{Závěr}

V předloženém textu je uvedeno pouze malé množství př́ikladů pohybových her, které lze aplikovat pro nácvik gymnastických dovedností. Je zde ještě velký prostor pro jeho rozšiřování. Učitel musí být schopen sladit zájmy dětí s výchovně - vzdělávacími cíli a záměry školní tělesné výchovy. Gymnastické aktivity mají pozitivní dopady na psychomotorický stav dětí a mládeže a právě tělovýchovní odborníci jsou zodpovědní za kvalitu vzdělání. Velké množství her umožňuje časté obměny a varianty jejich realizace, čímž je vytvořen předpoklad pestrého obsahu jednotlivých částí vyučovacích jednotek. Každá hra může být pro děti jak povzbuzením do další práce, tak zároveň rozptýlením po nezbytném udržování pozornosti či požadavku velkého soustředění v prováděných aktivitách.

Využívání gymnastického nářadí v hodinách školní tělesné výchovy spadá výhradně do specifických kompetencí pedagogických pracovníků - učitelů tělesné výchovy. Znalost materiálně technického vybavení a především pak umění ho využívat, vytváří předpoklady účelného a efektivního procesu vyučování a učení se.

Novodobé výrobní postupy a moderní technologie umožňují vyrábět takové nářadí, které výrazně usnadňuje nácvik a realizaci pohybových schopností a dovedností, zároveň zvyšují bezpečnost cvičení a díky svému designu mohou přispívat i k větší atraktivitě a zvýšení zájmu žáků o cvičení. Pokud by se podařilo vybavit tělocvičny jednotlivých škol moderním nářadím a využívat ho k pozitivním prožitkům hravou a soutěživou formou, mohl by se vztah ke gymnastickým aktivitám žáků ve školní tělesné výchově utvářet pozitivním směrem.

\section{Literatura}

Ahlquist, S. M., Russell, K. \& Fink, H. et al. (2010). Foundation of Gymnastics. Saskatoon, Canada: Ruschkin.

Ashy, M., Lee, A. \& Landin, D. (1988). Relationships of practice using correct technique to achievement in a motor skill. Journal of Teaching in Physical Education, 7, 115-120.

Bakalář, E. (1989). Psychohry. Praha: MF.

Bakalář, E. (1995). Psychohry 2. Praha: Vyšehrad.

Berne, E. (1992). Jak si lidé hrají. Liberec: Dialog.

Butler, J. (2005). Teaching games for understanding. Champaign: Human Kinetics.

Caillois, R. (1998). Hry a lidé. 1. vyd. Praha: Studio Ypsilon.

Cleeremans, A. (2002). Models of implicit learning. In Nadal, L. (Ed.) Encyclopedia of cognitive sciences (491-499). London: Macmillan Publishers. 
Csikszentmihalyi, M. (1996). O štěstí a smyslu života (Flow. The psychology of optimal experience). Praha: Lidové noviny. Dostál, A. \& Opravilová, E. (1985). Úvod do předškolní pedagogiky. 1. vyd. Praha: SPN.

Dvořáková, H. (2009). Pohybové činnosti pro předškolní vzdělávání. Praha: Raabe.

Feingold, R., S., \& Fiorentino, L. (2005). United States of America, In U. Pühse \& Gerber, M. (Eds.). International Comparison of Physical Education (699-713). New York: Mayer \& Mayer.

Huizinga, J. (1955). Homo Ludens. Boston: Beacon Press.

Chrudimský, J., Krištofič, J., Marek, J. \& Vorálková, J. (2012). Gymnastika v obrazech. Multimediální učební text. Praha: UK FTVS. Kössl, J., Štumbauer, J. \& Waic, M. (2002). Vybrané kapitoly z dějin tělesné kultury. Praha: Karolinum.

Mazal, F. (2000). Pohybové hry a hraní. Olomouc: Hanex.

Mazurovová, Z. \& Vlasáková, N. (1992). Pohybové hry ve sportovní gymnastice. Praha: Gym Game.

Neuman, J. (1998). Dobrodružné hry a cvičení v prírodě. Praha: Portál.

Neuman, J. a kol. (1999). Překážkové dráhy, lezecké stěny a výchova prožitkem. Praha: Portál.

Neuman, J. (2001). Dobrodružné hry v tělocvičně. Praha: Portál.

Perič, T. (2004). Hry ve sportovní prípravě dětí. Praha: Grada Publishing a.s.

Perič, T. (2012). Techniques of Learning to Assist Coaching. IIHF International Youth Coaching Symposium. IIHF, Helsinky (Fi). http://www.hockeycentre.org/inEnglish/Seminars/Seminars/2012IIHFInternationalYouthCoachingSymposium/ tabid/3034/language/en-US/Default.aspx (4.5.2012)

Silverman, S. (1993). Student characteristics, practice and achievement in physical education. Journal of Educational Research, 87 (1), 54-61.

Skopová, M. \& Zítko, M. (2005). Základní gymnastika. Praha: Karolinum.

Vorálková, J., Novotná, V. \& Šimůnková, I. (2013). Gymnastická hra jako podnět k modernizaci výuky gymnastiky ve školní tělesné výchově. Studia sportiva, 2, 111-116.

Werner, P. H. (2004). Teaching children gymnastics. 2nd ed. Champaign, IL: Human Kinetics.

Zapletal, M. (1985-1988). Velká encyklopedie her. Hry v př́rodě, Hry v klubovně, Hry na hřišti a v tělocvičně, Hry ve městě. Praha: Olympia.

Zítko, M. a kol. (2000). Všeobecná gymnastika. Speciální učební texty. Praha: ČASPV.

\section{Corresponding author}

PhDr. Jitka Vorálková, Ph.D.

UK FTVS, J. Martiho 31, 16252 Praha 6, Česká republika

voralkova@ftvs.cuni.cz 